\title{
TECHNOLOGIES OF TIMBER ASSORTMENTS HAULING BY TRACTOR-TRAILER TRAIN SQUADS
}

\author{
Mikhail Smirnov* Yuri Andrianov \\ Volga State University of Technology, Yoshkar-Ola, Russia
}

Technological variations of tractor-trailer timber hauling trains teamwork with tractor-mounted grapples (hydraulic manipulators) and without them are considered. The effective technology of timber assortments loading, transportation and unloading by tractor-trailer train squad is offered, which allows to reduce idle time of vehicles during terminal operations and in waiting.

Key words: Tractor-trailer train, Tractor-trailer train squad, Grapple, Loading, Unloading, Timber assortments, Work technique

\section{INTRODUCTION}

During last two decades Russia switched over to timber assortments hauling by tractor-trailer trains from harvesting areas or intermediate yards. The quantity of grapples for timber as-sortments loading and unloading installed on those trains increased $[01,03,07]$. Tractor-trailer trains with grapples frequently work together with those without them, no technology of their effective joint operation being developed. With a view of improvement of a tractor-trailer train squad op-eration, an effective technology has been developed, allowing to reduce the duration of idle time of tractor-trailer train squad waiting for loading and unloading [02, 05, 06, 08, 09].

The problems of timber cargoes transportation by motor transport were considered by many authors [12-18].

Equipping a tractor-trailer train with a tractor-mounted grapple has both benefits and drawbacks. Working autonomy, i.e. independence of other loading and unloading mechanisms; reduction of time wasted in waiting for loading and unloading; increase of labor utilization rate; lowering labor efforts and cost of handling operations, etc. are considered to be benefitial. Re-duction in allowable operating load of a tractor-trailer train conditioned by the need of carrying a loading device; increase in tractor-trailer train own weight by the weight of the loading equip-ment and auxiliaries; decrease in the weight capacity ratio of a bolster to a trailer; growth of spe-cific fuel consumption, necessary annual mileage, tires wearing, depreciation charges and cost of timber hauling; necessity of more qualified service may be considered to be drawbacks $[01,03,04]$.

To reduce negative influence of the loading grapple on technical and economic parameters of self-loading tractor-trailer train work is possible by their joint operation with tractor-trailer trains without loading equipment $[02$, 10]. The number of tractor-trailer trains with loading grapples and without them in a squad can be different.

\section{DISCUSSION AND METHODS}

The case with a squad consisting of three tractor-trailer trains, two of which (No 1 and No 3 ) are equipped with loading grapples and the rest one (No 2) is not, present significant practical interest. For this case two organizational schemes of a timber hauling process are offered.

\section{First organizational scheme}

Timber loading onto No 2 tractor-trailer train is constantly made by No 1 tractor-trailer train, and the unloading is executed by No 3 one. In this case the trip time of all tractor-trailer trains will be different. The working time scheme for one three tractor-trailer train squad trip is shown in Figure 1.

The quantity of time-based axes on the scheme equals to the number of tractor-trailer trains. The arrival time of a tractor-trailer train at the point of loading is marked as point 1 . It denotes the beginning of loading as well. Point 2 denotes termination of No 3 tractor-trailer train loading and its leaving the point of loading. No 2 tractor-trailer train is loaded by No 1 tractor-trailer train. Termination of No 2 tractor-trailer train loading and its departure from the point of loading are marked by point 3 . No 1 tractor-trailer train remains at the point of loading and loads itself, point 4 corresponding the termination of loading. No 3 tractor-trailer train arrives first at the point of unloading and starts to unload itself, which is marked as point 5; point 7 denotes termination of the unloading. The time interval on the second axis between points 6 and 7 corre-sponds to idle time of No 2 tractor-trailer train waiting for unloading.

After termination of works at the point of unloading (point 8) No 2 and No 3 tractor-trailer trains stand idle waiting for No 1 tractor-trailer train to begin next trip simultaneously. The dura-tion of idle time corresponds to the time interval between points 8 and 10, which increases the trip duration, reducing the efficiency of shift working hours use. 


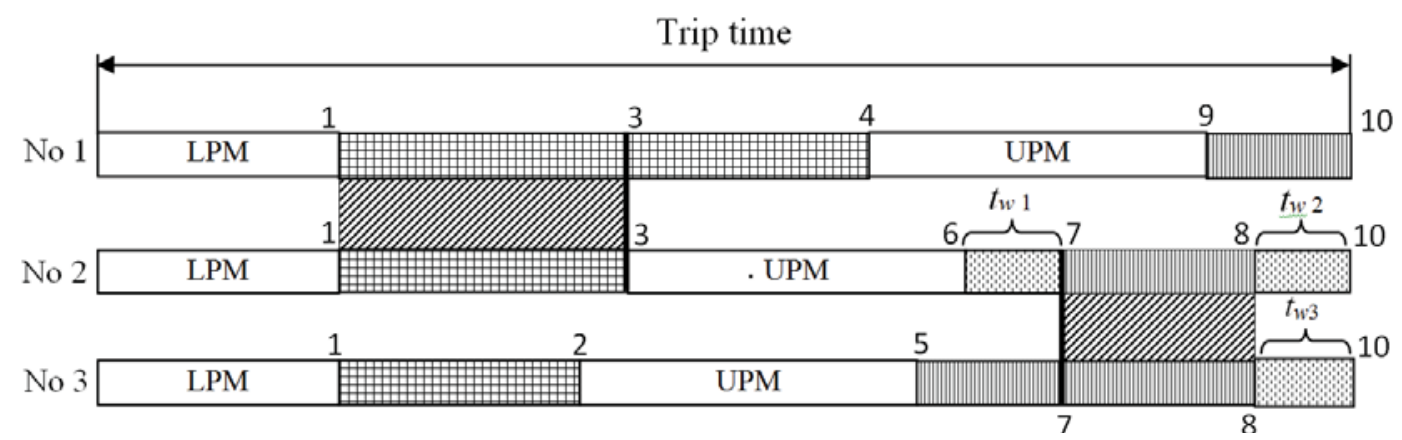

Figure 1: Working time scheme for a three tractor-trailer train squad (scheme 1):

LPM - movement to loading point; UPM - movement to unloading point

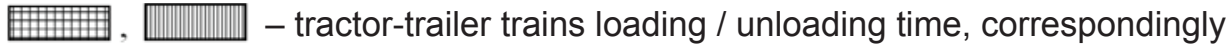

\% - idleness when waiting for loading / unloading

ШाIIIIS - joint work of tractor-trailer trains

\section{Second organizational scheme}

In order to reduce the idle time of tractor-trailer trains at the points of loading and unloading and the duration of trips, the joint work of tractor-trailer trains is offered. The greatest effect of the second working time scheme (Figure 2) is achieved when an even number of trips is performed.

In the first trip No 1 tractor-trailer train loads timber onto No 2 tractor-trailer train, which is marked as point 1 ; then it loads itself, point 3 . No 3 tractor-trailer train is loaded with timber and begins its movement to the point of unloading, point 2 . It unloads at the point of unloading (time interval between points 5 and 7 ), then unloads No 2 tractor-trailer train (time interval between points 7 and 8 ) and they begin next trip together. No 1 tractor-trailer train arrives at the point of unloading later than No 2 and No 3 tractor-trailer trains (point 9), so it leaves for the point of loading later as well (point 10). No 2 and No 3 tractor-trailer trains come back to the point of loading together. No 3 tractor-trailer train starts loading, point 11; and then it loads itself, point 12. No 1 tractor-trailer train, having loaded itself with timber, goes to the unloading point where No 2 tractor-trailer train stands idle waiting for unloading.

The duration of idle time of No 2 tractor-trailer train waiting for unloading (Figure 2) corre-sponds to the time interval between points 16 and 17 . The unloading of No 2 tractor-trailer train is made by No 1 one. All tractor-trailer trains in a squad finish the second trip simultaneously. Further the cycle is repeated.

Studies of the suggested working schemes (Figures 1 and 2) for a loading-transportation squad consisting of three tractor-trailer trains two of which have loading grapples are undertaken with the help of imitating model [02].

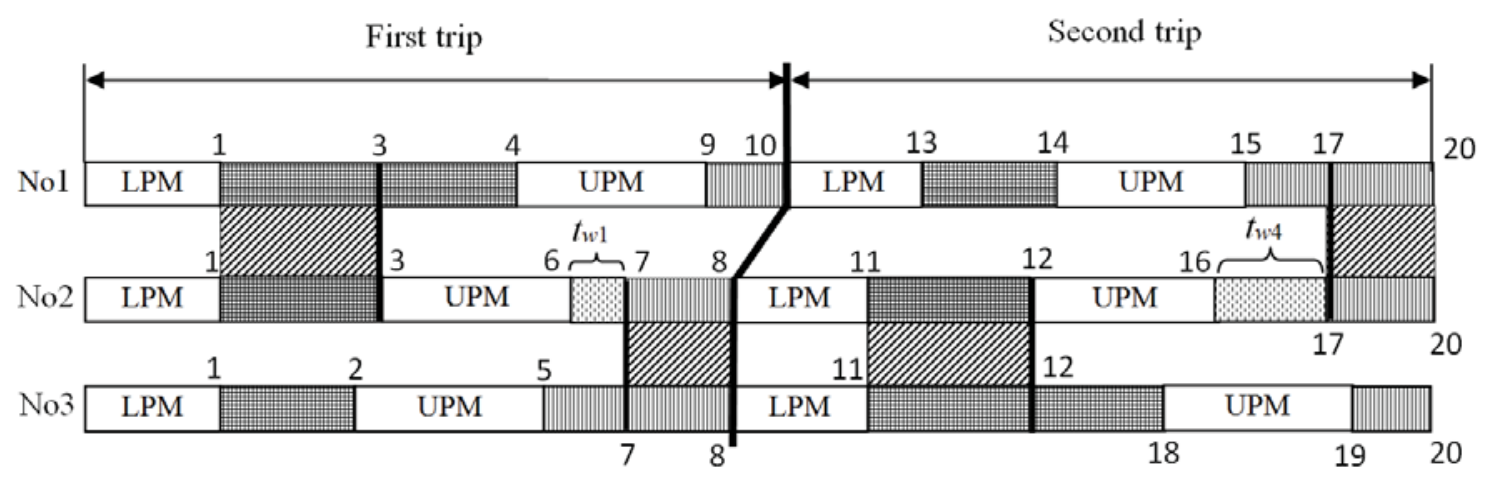

Figure 2: Working time scheme for a three tractor-trailer train squad (scheme 2) 
The scheme (Figure 3 ) obtained as a result of preliminary experimenting with the model shows that given the identical trip loadings of all three tractor-trailer trains in a squad, idle time of the tractor-trailer train without a loading grapple is inevitable.

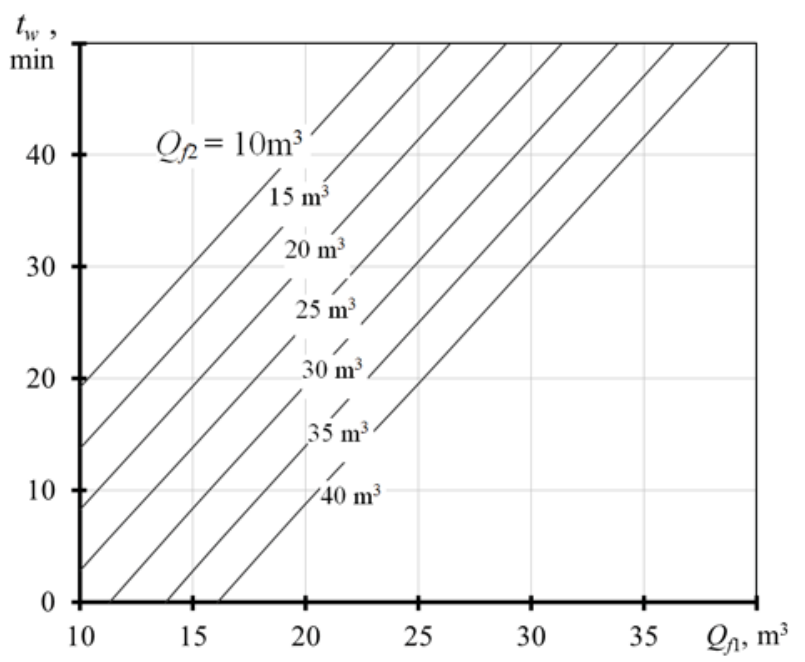

Figure 3: Changing idle time of No 2 tractor-trailer train in waiting for loading-unloading ( $1^{\text {st }}$ scheme)

Increase in trip loading $Q_{\mathrm{f} 2}$ in comparison with trip loading of self-loading tractor-trailer trains $Q_{f 1}$ allows to reduce idle time of an object waiting for terminal operations. For example, given trip loading of self-loading tractor-trailer trains $Q_{\mathrm{f} 1}=10 \mathrm{~m}^{3}$ and increase in trip loading of a tractor-trailer train being served $Q_{\mathrm{f} 2}$ up to $20-25 \mathrm{~m}^{3}$, the average size of its idle time in waiting for servicing will be insignificant (3-8 min); given $Q_{\mathrm{f} 1}=20 \mathrm{~m}^{3}$, trip load $Q_{\mathrm{f} 2}$ should make $35-40 \mathrm{~m}^{3}$ on the average. The work of a squad under the second scheme allows to reduce idle time of a tractor-trailer train without a grapple in waiting for loading and unloading.

\section{RESULTS}

Industrial check of the offered schemes of joint operation of self-loading and non-equipped with a grapple tractor-trailer trains was carried out at Marlesprom LLC of the Republic of Mari El. The following tractor-trailer trains were chosen as research objects: Ural-4320+TM3802+ОМТЛ-70-02 (Number plate В036СК), Ural4320+ТМ3-802+ОМТЛ-70-02 (Number plate В037СК), KamAZ-5320+СЗАП-83571 (Number plate В042CК). During the industrial check $2000 \mathrm{~m}^{3}$ of timber were loaded, hauled and unloaded.

The organization of tractor-trailer trains work under the offered technological scheme (Table 1) allowed to increase their output per shift 1.2 times, to reduce labor expenditures for basic and auxiliary workers, payment expenses for labor as well as carrying equipment maintenance. Total operational costs decreased 1.2 times.

Under the first working scheme, total idle time in terminal operations for No 2 tractor-trailer train during one trip amounted to 18.5 per cent of the total duration time of the trip, as the object being served has to wait at loading-unloading point for termination of loading and unload-ing of a self-loading tractor-trailer train to begin movement simultaneously. Change of the work-ing scheme of a loading-transportation squad allowed to reduce idle time for No 2 tractor-trailer train being served when waiting for loading and unloading up to 2.8 per cent of the trip duration time.

When comparing the working schemes of a tractor-trailer train squad, it should be noted that the same volume of $1000 \mathrm{~m}^{3}$ forest products was hauled. The forest products were taken from one and the same wood cutting area, the hauling distance was $14 \mathrm{~km}$. So, identical working conditions were provided for each working scheme, including road, loading-and-unloading, and transportation ones.

As a result the following advantages of the second working scheme of a tractor-trailer train squad were obtained in comparison with the first scheme:

- output of a squad per shift grew by $14.9 \mathrm{~m}^{3}$, i.e. by $23 \%$;

- number of basic workers personnel hours for loading, hauling and unloading of for-est products decreased by 10 man days, i.e. by $21 \%$;

Table 1: Comparative characteristics of a tractor-trailer train squad operation scheme

\begin{tabular}{|c|c|c|}
\hline Parameter name & \multicolumn{2}{|c|}{ Operation scheme } \\
\cline { 2 - 3 } & 1st & $2^{\text {nd }}$ \\
\hline 1. Timber hauling volume, $\mathrm{m}^{3}$ & 1000 & 1000 \\
\hline 2. Hauling distance, $\mathrm{km}$ & 14 & 14 \\
\hline 3. Output of a squad per shift, $\mathrm{m}^{3} / \mathrm{cm}$ & 63.8 & 78.7 \\
\hline $\begin{array}{c}\text { of } \\
\text { of forest products, man-day }\end{array}$ & 48 & 38 \\
\hline 5. Labor expenditures of basic workers on loading, hauling away and unloading & 17.3 & 16.2 \\
\hline 5. Expenditures on repair and maintenance of basic equipment, man-day & 67.38 & 51.76 \\
\hline 7. Specific operational expenses, rub $/ \mathrm{m}^{3}$ & 263.13 & 222.53 \\
\hline
\end{tabular}


- number of personnel hours for repair and maintenance of the capital equipment re-duced by 1.1 man day, i.e. by $6 \%$;

- $\quad$ expenses for fuel and lubricants decreased by15.62 rubles / m3, i.e. by $23 \%$.

The results of the research work are accepted to use in Marlesprom LLC of the Republic of Mari El. The enterprise switched to forest products hauling by a tractor-trailer train squad, using the working scheme offered.

\section{CONCLUSION}

The offered operation technology of a squad of three tractor-trailer trains, two of which are equipped with hinged grapples, allowed to reduce idle time of a tractor-trailer train without a grapple by 6 times, to lower assortments hauling cost, to increase productivity and efficiency of hauling tractor-trailer trains exploitation.

\section{REFERENCES}

1. Andrianov, Yu.S. (2001) Timber hauling by self-loading tractor-trailer trains: Scientific publication / Yu.S. Andrianov. Ed. by M.Yu. Smirnov. - Yoshkar-Ola: the MSTU, $231 \mathrm{p}$.

2. Smirnov M.Yu., Bakulina I.R. (2009) Modeling of work of a loading-transportation unit of a log truck. Vestnik of the MSTU. Ser.: Forest. Ecology. Nature management. 1, 41-51.

3. Smirnov, M.Yu. (2003) Operational improvement of timber hauling by tractor-trailer trains: Scientific publication / M.Yu. Smirnov.- Yoshkar-Ola: MSTU,280 c.

4. Smirnov M. Yu., Bakulina I.R. (2013) Wall-mounted hydraulic manipulator work cycle time. Vestnik of the VSUT Ser.: Forest. Ecology. Nature management. 3, 72-81.

5. Smirnov M.Yu., Bakulina I.R. (2011) Economic efficiency limits analysis of loading, transportation and unloading of timber with the help of road trains link. Vestnik of the MSTU. Ser.: Forest. Ecology. Nature management. 1, 39-51.

6. Smirnov M.Yu., Bakulina I.R. (2010) Bases of furnishing a loading-transporting squad of timber hauling tractor-trailer trains: monography / M.Yu. Smirnov, - Yoshkar-Ola: MSTU, 152 p.

7. Smirnov M.Yu. (2002) Calculation of bearing capacity of vehicle with hydraulic handling device. Bulletin of higher educational institutions. Lesnoy zhurnal. 4, 71-76.

8. Smirnov, M.Yu. (2007) Results of industrial research of technological schemes of a load-transportation squad operation / M.Yu. Smirnov, I.R. Bakulina // Science in a contemporary con-text: Collection of scientific articles. - Yoshkar-Ola: MSTU, 2007. - Pp. 132-135.
9. Smirnov, M.Yu. (2008) Improvement of the process of forest products transportation on the basis of self-loading tractor-trailer trains / M.Yu. Smirnov, I.R. Bakulina // Innovative devel-opments of higher school science for the economics of Russia: Collection of scientific works of the All-Russia scientific and technical conference. - Yoshkar-Ola: MSTU, 2008. - Pp.197-201.

10. Smirnov M.Yu., Gabdullina I.R. (2005) Improvement of timber hauling tractor-trailer trains squad operation. Bulletin of higher educational institutions. Lesnoy zhurnal. 6, $112-117$.

11. Smirnov, M.Yu. (2007) Analysis of operation variations of timber hauling tractor-trailer trains / M.Yu. Smirnov, Yu.S. Andrianov // Nastoleni moderni vĕdy (1-15 sáŕí 2007 roku): Materialy VI mezinárodní vĕdecko - praktiká konference.- Dil 5. Techniké vĕdy. Matematika. Fizika. Moderni informačni technologie. Vŷstavba a architektura: Praha. Publishing House «Ed-ucation and Science»s. r. o, 2007.-Stran.37-39.

12. Carlsson, D., and M. Rönnqvist. 2007. Backhauling in forest transportation - models, methods and practical usage. Can. J. For. Res. 37(12).

13. Malinen, J., V. Nousiainen, K. Palojarvi, and T. Palander. (2014) Prospects and Chal-lenges of Timber Trucking in a Changing Operational Environment in Finland. Croat. J. For. Eng. 35(1):91-100.

14. Shaffer, R. M., and W. B. Stuart. (2009) A checklist for efficient log trucking. Availa-ble online at: https:// vtechworks.lib.vt.edu/handle/10919/54904; last accessed February 19, 2016.

15. Zamora-Cristales, R., and J. Sessions. (2015) Are double trailers cost effective for transporting forest biomass on steep terrain? Calif. Agric. 69(3):177183.

16. Gallagher, T., McDonald, T., Smidt, M., Tufts, R., (2005) Increasing Truck Payloads and Performance. Wood Supply Res. Inst. Technical Release.

17. Shivan G. C., Potter-Witter, K., (2011) An examination of Michigan's logging sector in emerging bioenergy market. For. Prod. J. 61:459-465.

18. Murphy, G., (2003) Reducing Trucks on the Road through Optimal Route Scheduling and Shared Log Transport Services. South. J. Appl. For. 27(3):198205

Paper submitted: 06.02.2018.

Paper accepted: 15.05.2018.

This is an open access article distributed under the CC BY-NC-ND 4.0 terms and conditions. 